\title{
Factors Affecting Reading Performance Of Primary Four School Children: The Case Of University Practice School (South Campus) Winneba)
}

\begin{abstract}
This study examines the inhibiting factors affecting reading as a medium of instruction for primary four pupils in the University Practice Primary School (UPPS) at Winneba. Unfortunately, reading which is supposed to be a medium of communication had rather become a challenge by the aforementioned pupils. In this study, both quantitative and qualitative designs have been applied to address this gap. The findings of the study revealed that out of the thirty-two pupils tested, using the 100 high-frequency words for word recognition, only four (4) pupils attained a mastery level of $80 \%$. Thus, rendering the remaining pupils as poor readers. The study recommends that pupils with reading difficulties may need more periods on the academic time table to read in order to overcome their problems. Furthermore, teachers must give much attention to pupils with such challenges.
\end{abstract}

Keywords: Reading, reading performance, Reading challenges, Teaching approaches.

\section{EVELYN SUSUANA \\ AYORKOR ASUMANG ${ }^{1}$}

${ }^{1}$ Evelyn Susuana Ayorkor Asumang (MPhil), is a Tutor and Head of Department at the Presbyterian College of Education, Akropong-Akuapem. She is a PhD Candidate in Special Education at the University of Education, Winneba, Ghana.Email: anglowevelyn20@gmail. com

\section{Manuscript}

Received 21st April 2020, Accepted 1st June 2020,

Published online 16th June 2020.

\section{INTRODUCTION}

The whole world is set on the path of achieving Education for all by the year $2020 .{ }^{2}$ Empowerment of all classes in society through literacy is the first step in the process because the ultimate goal is lifelong learning and reading is the instrument par excellence for acquiring the necessary skills for the pursuit. The ability to read and comprehend any subject is vital to achievements in all academic endeavors. Thus, the inability to fulfill this purpose hinders academic performance in almost all subject areas. ${ }^{3}$

In the Ghanaian educational system, the poor performance of some school children at the basic level has generally become a serious national concern. Reading problems are the major causes of the referrals and failures of pupils in most schools. ${ }^{4}$ Thus, the child who cannot read has little success in school and there is the need to "catch them young" before they fail. Series of reading clinics had been held by the University of Education, Ghana, in collaboration with Virginia State Reading Association, USA. Some selected basic schools in the Awutu-Efutu Senya municipality took part in this exercise to enhance reading skills in recent years yet, research findings in the area, indicated a low performance in their examinations at the basic level and even continued to the Junior High Schools, Senior High Schools and even to the Universities. This prevents most school-going age children at Winneba to fully integrate into the learning environments in the school. This fact was substantiated recently by the Municipal Chief Executive of Awutu-Efutu Senya when he visited the stool chief at Winneba. ${ }^{5} \mathrm{He}$ established that about $70 \%$ of the learning difficulties of children are attributable

\footnotetext{
S. Hook, Education for modern man: Wipf and Stock Publishers, 2020

3 U.T. Oyetunde, (Ed)., Helping Children Become Good Readers: A Guide for Parents and Teachers. Jos: P.P Reading Association of Nigeria, (2000)

4 Chief Examiners' Report, Basic Education Certificate Examination (Accra, The West African Examination Council,2006).

5 Municipal Chief Executive's Report on Reading Performance. Awutu-Efutu Senya: Radio Peace, April 18, 2006.
} 
to poor reading skills. It is therefore a matter of concern that despite the presence of the University in the Municipality, school children are performing poorly in reading. This study therefore, seeks to examine the inhibiting factors affecting reading as a medium of instruction for Primary four pupils at (UPPS), Winneba in the Central Region, Ghana.

Many children at the University of Education Practice Primary School which is located within the Winneba area have reading problems and difficulties that are affecting their performances. Learning to read poses real challenges, even to children who will eventually become good readers in the school. Due to these problems majority of the children end up dropping out of school. These problems need to be taken care of in time; if not these children will be promoted to the next class until they get to the final stages of writing the Basic Education Certificate Examination (BECE). What then happened to some pupils in the year 2000 may also happen to them. They might probably grow with the problem even to the adult stage.

Reading problems is one of the causes of poor performances in class and a source of social exclusion within the wider society. In the University of Education Practice Primary School, (UPPS) several children are unable to read. The inability to read and make sense out of a text affects the performance of some of these children. ${ }^{6}$ The inability of school pupils to read and comprehend examination questions has also been noted by the Chief Examiner in the WAEC report and has consequently led to a general decline in the standards of Education in Ghana. ${ }^{7}$ It is not so clear what the factors accounting for this non-performance are but for the initiative and effort of some teachers at UPPS South Campus, some pupils are unable to read and do demonstrate some lack of interest in reading.

Even where effort is put in reading some of the pupils in Basic Four (4) do not read materials that are ageappropriate or at their grade level. Homework and other related assignments are often brought back unanswered. Furthermore, although teachers in UPPS put in considerable effort in supporting reading, it is not clear what specific strategies are adopted by these teachers. These are the issues upon which this study is hinged.

\section{METHODOLOGY}

The research deployed a case study with a mixed-method approach that involves collecting, analyzing and integrating quantitative (e.g. test) and qualitative approaches simultaneously. This approach is useful in understanding the contradictions between quantitative results and qualitative findings for the findings to be grounded in participants' experiences. The study was carried out at the University of Education, Practice Primary Four 'B' (South Campus) at Winneba. This school was appropriate for this study due to the examining factors affecting particular school children's reading performances which happen to be a model practicing school for university students thus expected to perform better. The sample for this study consisted of thirty-five participants comprising of 17 primary ' $\mathrm{B}$ ' girls and 15 boys, with their average age between nine (9) to eleven (11) years. Two (2) class teachers and one (1) headteacher who had all attended a reading course organized by the International Reading Association in collaboration with the University of Education, Department of Special Education was also studied. The justification for selecting primary four (4) was that this stage marks a transitional period of moving from the lower primary to upper primary stages, where much awareness in reading performance is expected of most children. Methods of inquiries were based on tests, observation (checklist) and interviews. In this study, an achievement test battery which is a tool constructed to evaluate the Phonological Decoding and the Reading Comprehension of pupils. This test requires the completion of cognitive tasks as a guide for administering and recording the test scores of the participants in the study based on research objective one (1) raised in the study. Observation in a checklist form was also used following over a pattern of verbal interactions between pupils and staff through classroom activities. A semi-structured interview- guide was developed by the researcher and was used to solicit responses from the 35 interviewees. The reason was to gain an insight into the child's reading world. In finding out the factors affecting children's reading performance in the school understudy, a descriptive statistic was employed to test whether the pupils have reached a mastery level of $80 \%$. A simple percentage was used. The interview data was categorized into themes in line with the objective of the study. Sub-themes were further developed and meanings through words, phrases or events were assigned to them based on the literature reviewed.

\footnotetext{
6 N. C. Boison, Development and uses of a 100 High Frequency Sight Words Recognition List for Children with reading failure: in A, E Ama (ed.), Reading for all in Africans: Building Communities where Literacy Thrieves (Newark, DE: International Reading Association, 2005).

7 Chief Examiners' Report, Basic Education Certificate Examination (Accra), 19-27.
} 


\section{FINDINGS}

These findings were presented concerning the objectives of the study. Level of reading performance among pupils;

Table 1: Pupils Level of Reading Performance

\begin{tabular}{|c|c|c|}
\hline Score & No. of Pupils & Percentage\% \\
\hline 6 & 1 & 3.1 \\
\hline 12 & 1 & 3.1 \\
\hline 13 & 1 & 3.1 \\
\hline 14 & 1 & 3.1 \\
\hline 15 & 1 & 3.1 \\
\hline 16 & 1 & 3.1 \\
\hline 17 & 2 & 6.3 \\
\hline 18 & 1 & 3.1 \\
\hline 25 & 1 & 3.1 \\
\hline 27 & 1 & 3.1 \\
\hline 30 & 1 & 3.1 \\
\hline 37 & 1 & 3.1 \\
\hline 41 & 1 & 3.1 \\
\hline 45 & 2 & 6.3 \\
\hline 46 & 1 & 3.1 \\
\hline 47 & 1 & 3.1 \\
\hline 49 & 1 & 3.1 \\
\hline 67 & 1 & 3.1 \\
\hline 69 & 1 & 3.1 \\
\hline 70 & 1 & 3.1 \\
\hline 71 & 3 & 9.4 \\
\hline 75 & 2 & 6.3 \\
\hline 76 & 1 & 3.1 \\
\hline 85 & 1 & 3.1 \\
\hline 98 & 1 & 3.1 \\
\hline 100 & 2 & 6.3 \\
\hline
\end{tabular}

The results from Table 1 shows that out of the 32 pupils only 4 representing $12.5 \%$ attained mastery level of $80 \%$ and above of a class one (1) level material in word recognition.

The table also showed that only nine (9) pupils representing $28.1 \%$ out of the 32 pupils who could not attain the mastery level also recognized words at sight to an appreciable level of $50 \%$ and above indicating high achievers. Their highest score ranges from $67 \%$ to $76 \%$ from the table.

Considering the table above, it was again realized that nineteen (19) pupils representing $59.4 \%$ of pupils out of the 32 pupils performed below average with the highest $49 \%$ and the lowest $6 \%$ out of the 100 high-frequency words tested on pupils to ascertain their level of performance on reading. Based on the only four (4) pupils attaining mastery of $80 \%$ in a reading test score using a basic one (1) level reading material for primary four revealed that their reading performance level is not encouraging.

\section{Children's attitude towards reading}

Structured observation, in the form of a checklist data was gathered by the researcher through visual and auditory observation on oral language skill acquisition of pupils; speech-to point match and silent reading behaviors. Below are the frequencies and bar charts on the oral language skill of the pupils. 
Table 2: Oral Language Skills of Pupils

\begin{tabular}{|l|l|}
\hline Observation & Frequency \\
\hline DA & 114 \\
\hline NME & 152 \\
\hline
\end{tabular}

KEY:

DA - Developing Adequately

NME - Needs More Experience

Table 2 was geared towards two of the issues posed in the observation checklist which were oral language skill and speech-to-print-match-behaviors. Below are the frequencies and bar chart on the oral language skill of the pupils.

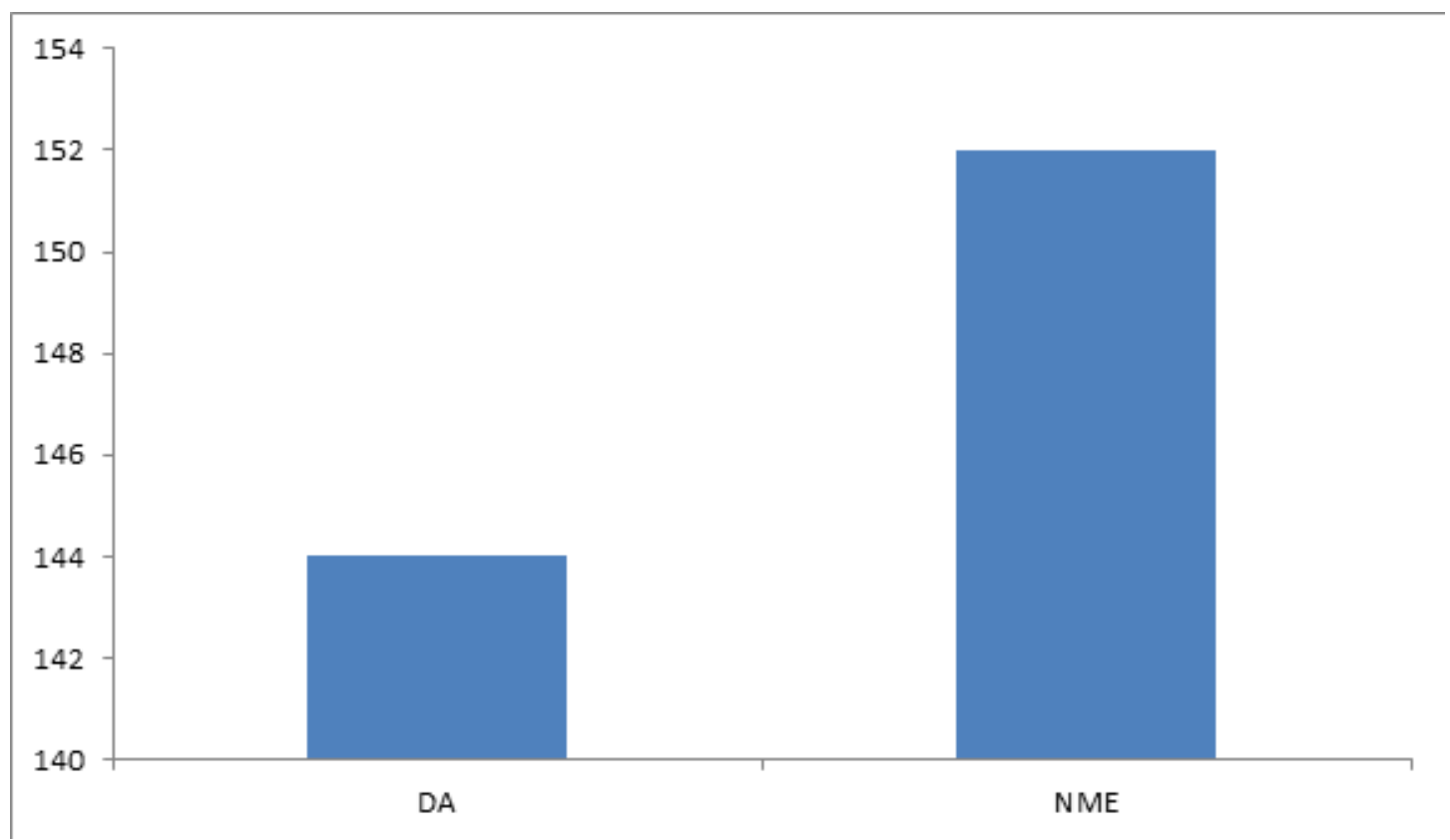

Figure 1: Frequency Distribution of Oral Language Skill Performance of pupils

From Figure 1, the oral language skill category solicited for information on children's general habit formed in reading following directions for Language Experience Approach (LEA) material prepared by the pupils for oral reading. Items observed under this skill were all (9) in number on habit formation in reading. Item 1, sought for children's participation during a group discussion in reading. Item 2, also checked on pupils answering of questions after a reading lesson to check if pupils speak in complete sentences. Item 3, sought to check on how pupils relate words and pictures. Item 4, purposed to check on how best pupils retell stories in proper sequences and item 5 checked on how best pupils describe simple objects. Item 6 was purposed to see if pupils make story predictions based on title or an illustration. Item 7, checked on whether punctuations are read correctly. Item 8 , also checked on pupil's fluency in reading material, the last item which is 9 , sought to look at how best pupils could express themselves.

Illustrated in the table above are the individual scores attained by each pupil. It could be seen that 5 pupils constituting $15.6 \%$ did not respond to any of the nine (9) items under oral language during reading exercise in the study. Again, only 6 pupils out of the 32 pupils answered all the items under oral language correctly (DA).

As illustrated in Table 2, there was a frequent occurrence of NE with 152 checks and a lesser number for DA respectively on the bar chart. This indicates that the majority of the pupils need more experience so far as oral skillful reading is concerned.

\section{Pupils' attitude towards speech-to-print-match during reading}

Table 3 sought pupils to point to words as teachers or peers read and answer questions correctly using appropriate speech sounds. This was used to ascertain the pupil's engagement with the literature. 
Table 3: Pupils Attitude Towards Speech-to-Print-Match d

\begin{tabular}{|l|l|}
\hline Observations & Frequency \\
\hline DA & 93 \\
\hline NE & 33 \\
\hline
\end{tabular}

KEY

DA- Developing Adequately

NME - Needs More Experience

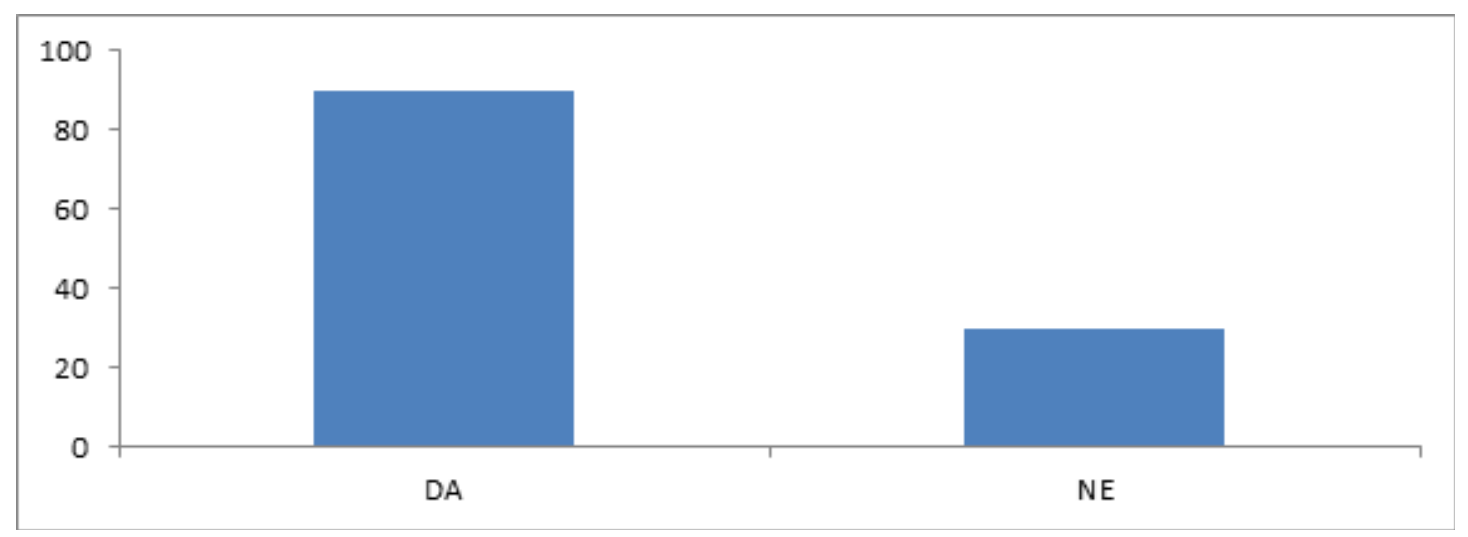

Figure 2: Performance of Pupils Attitude Based upon Speech to Print-Match Skills

As illustrated in Tables 3, C\&D above is the presentation of the pupil's attitude to reducing based upon speech to printmatch skill, which sought pupils to point to words as they were read to. This was used to ascertain behaviors children exhibit during reading.

The skill is made up of 4 items:

- Item 1, purposed to see if pupils point to written words as they are reading aloud.

- Item 2, sought to check on whether pupils indicated where printed messages begin on-page.

- Item 3, also checked on the directional orientation of print (left to right).

- Item 4, sought to check on pupils' knowledge on some words in isolation.

From the tables above it could be observed that nineteen (19) pupils constituting 58\% out of the 32 pupils were able to conform well to the reading habit formation. They responded to all four items under speech-to print-match. A pupil had three of the items correctly under DA. Five (5) of the pupils had only two (2) items correctly. Four (4) pupils also responded to an item constituting $12.5 \%$. Illustrations on the frequency table indicate that for this particular skill most pupils did very well under DA and did not need more experience. They followed the literature they were engaged in close to words standing out in isolation. The table showed clearly that, in certain cases, the pupil's task concentrations were quite high, evidently, 93 checks of pupils developing adequately over 33 checks of Needs more Experience.

\section{Factors Affecting Reading Performance}

The themes generated from this study were pupil's reluctance to visit the library, growing disinterest and a general dislike for reading, a large number of pupils in one class, complex reading books and foreign literature present in the library.

\section{Reluctant to visit the library}

An analysis of the interview results revealed a general unwillingness on the part of many of the participants or perhaps fear on the part of pupils to visit the library as some pupils expressed;

"I see the library but I am afraid to go there". (transcribed expression).

"I don't go to the library because I feel shy". (transcribed expression).

The author was unable to establish the real cause of the fear of visiting the library as was the reason the pupils felt this way. It seemed however that, the difficulty of speaking good English and the inability of some of the participants to respond appropriately could have been one of the factors, as one respondent noted:

"......... library at all, the woman by the gate asks too many questions, and since I can't speak good English, I don't go there”. (transcribed expression). 


\section{Growing disinterested and dislike for reading.}

Apart from the unwillingness to use the library, some of the participants were generally uninterested in reading. One pupil, for instance, remarked as follows;

".................... I don't read at all”" (transcribed expression).

Another stated:

“....... I don't like reading... I like football” (transcribed expression).

This demonstrated that very little was happening regarding reading activities even within the school and therefore pupils were not sufficiently motivated. The frequency with which the construct "hate" featured in the discourse of the participants revealed an underlying aversion for reading. Many of the participants commented as follows:

“...... Don't like reading....... I don't know why that is so... I hate class reading. I don't like reading; people

laugh at me so I hate it. I hate to read, but I like games." (transcribed expression)

“........... I read before once in class, pupils laughed at me.” (transcribed expression)

Above all, however, the general dislike for reading at this insipient age raises several critical issues and concerns regarding the reading habits and interest in reading of the participants. However, a few of the participants also expressed interest in the number of things they read;

"I read a lot say...... six times depending on the type of lesson or reading book I am having at hand. Even today I finished reading a chapter in the bible about Lot's wife found in Genesis 19:23 after which I read thoroughly a prayer for memorization in the devotional guide my daddy bought for me. The title is Rhapsody of Realities: As for the author of the book I last read, I can't remember. Eh...... I have forgotten. I don't normally put them in my mind" (transcribed expression).

Another stated that:

"I read about eight books in a month on a signpost, newspapers like (junior graphic, notices on board at the office, inscriptions on cars, my Bible, letters, reading items on the T.V and the internet café. The last time I read a book was yesterday in the night. It was quite interesting and was about "ROALD DAHL" BOY tales of childhood" (transcribed expression).

\section{Complex reading books}

In an interview analysis, comments from most of the participants however expressed their displeasure towards reading materials in many ways:

“............. I don't read always because the books I normally read are too difficult for me to understand.

Because of that, I lost interest in reading books. But I read the P.4 English reader nicely. For the title, I don't remember". (transcribed expression).

Another commented:

"......... I struggle before I can finish one book and sometimes, I just don't understand them let alone sounding the words. Because of my weakness, I have no interest in books. My mates laugh at me so nowadays I don't read at all because my teacher doesn't have patience and time for children like me who will read one-by-one" (transcribed expression).

Another remarked:

“............... I don't even remember the last time I read a book; you see my teacher hates me for that because even in class I refuse to read. You see nobody likes those of us who read slowly. I even plan to stop coming to school because I feel so embarrassed". (transcribed expression).

\section{Large numbers in class}

Some of the difficulties encountered by children during reading were stated as;

“.... we have so many problems in learning the skills of reading because our number on roll is too much so no teacher allows us to engage in the process of reading enough to acquire a setup of vocabulary words". (transcribed expression).

".... We are not put in small groups to learn from the fast readers because of lack of furniture, and so only a few with tables and chairs read and small-time the time is up so they always achieve better". (transcribed 
expression).

Other participants also attributed the difficulties to their teacher's inability to pay attention to all individuals in the class but only to some best readers only as noted by one of the participants;

"Hmm! Only the best readers engage the attention of the teacher but for us, no attention is paid to us". (transcribed expression).

\section{Foreign Literature}

Other reasons given for the difficulty encountered in reading seem to be influenced by the difficult nature of some foreign books read with very tough words.

“...... I don't read stories; I read only my notes, that one I understand them. Teachers do not teach us how to pick simple storybooks. All the stories are difficult to understand. The words are not from Ghana and you can't understand the book". (transcribed expression).

\section{Strategies of teaching provided to the pupils at UPPS by the teachers.}

Teachers were interviewed with regards to the strategies they consider appropriate in helping pupils read and the results revealed that teachers used limited approaches in teaching how to read.

\section{Limited approaches to teaching}

An analysis of one of the themes revealed that teachers used only two strategies in helping children learn to read. For example, one of the two teachers interviewed remarked;

"I help them by reading their basal readers aloud. Not all the class anyway, each pupil reads for others to listen. After some time, I stop whoever is reading to check if all children are following the reading (Verbatim expression of teacher $A$ ).

Teacher ' $\mathrm{B}$ ' was also contacted to find out how she goes about instructions in a reading lesson. She had this to say: "The children's number on roll is a problem so some do not follow the reading but when asked to point; they follow what those key readers point to and also point to the same" (Verbatim expression of Teacher B).

Remarks like this showed that very little is happening to those pupils in a class with reading problems. Only the voices of key or fluent readers are paid attention to. This reaffirms what a pupil commented on:

"We are many in the class and no attention was given to any dull reader in the class since the reading period too is short"

\section{Basal reader approach}

A sub-theme rising from the transcript analysis indicated that the class four (4) basal readers were the only materials used in teaching children to read.

"The fact is that the children use only class four basal readers and it is read for only 30mins" (Teacher A).

"We have other materials to help the children given to us by the university through friends from the Virginia State Reading Association but a book or two cannot suffice the whole class so I avoid using them and solely depend on the basal reader" (Teacher B).

\section{Inadequate supervision by the Headteacher}

Another sub-theme emerged from the headteacher indicating how she perceives the seriousness of the pupils' inability to read and she had this to say:

“.........hmm! I must be frank with you I am not able to visit my teachers frequently in their various classroom during reading because of administrative duties. I go for meetings at the district education office many a time". (verbatim expression from headteacher)

A follow-up question was demanded from her concerning why she could not relinquish duties to her assistant? And she had this to say:

"........ my assistant had been in the kindergarten class for 16 years, and you are dealing with basic four pupils transitional reading progress from the lower primary to upper primary. I realized she has no interest and so there must be more incentives and motivation for teachers to perform better, with the best of strategies." (verbatim expression of the headteacher). 


\section{DISCUSSION}

The finding of the study revealed that $80 \%$ of the pupils had language problems such as English language comprehension, receptive and expression language and $60 \%$ also had language cognitive problems. These results affirm the previous work conducted by Donani and Avoke. ${ }^{8}$ The results from the two authors also showed that $75 \%$ of upper primary and junior high school pupils had language problems. Furthermore, apart from the language experience approach (LEA) material constructed earlier, all other materials used for the study were drawn from primary one (1) yet they had problems in reading and understanding a text.

In line with the cognitive problems encountered, there is a need for teachers to apply the literature on cognitive theory to classroom instruction through modeling of reading lessons. This is done by interacting with the children and also being a good listener. Besides, the teacher has to be a speaker, a questioner and a friend. These aforementioned qualities will help encourage the pupils and improve their critical thinking abilities. ${ }^{9}$ Teachers are to present learning in a manner that is intended to serve the learner's future, thus they are to create an activity that will serve both pleasurable and practical purposes. These will help the child to take a reasonable decision in learning to read.

Studies on children's oral language and reading comprehension as already stated in the literature have yielded findings of the role of sentence structure in reading. The inability to understand a written text is often the result of differences between a child's facility with oral language and the structure of written language. ${ }^{10}$ In line with literature in a speech to print match, it was however detected that defective speech is associated with reading difficulties. ${ }^{11}$ Bader in his work stated that the command of the oral language is the foundation of success in reading and writing. ${ }^{12}$

It is therefore important that pupils participate in listening and speaking activities each day from teachers and parents in helping children succeed in reading. The lack of confidence in the use of spoken English is traceable in part to poor reading habits and such was accountable for the reluctance to use the library. Briton suggests that the usual practices of teaching children to read in the primary schools with the help of reading schemes, kits and apparatus without necessarily taking them to visit the library where there are stocks of books may prevent children from discovering the importance of reading. Briton further suggested that that, a pupil who visits the library frequently and pretends he is reading a story on the road to success than those who are not exposed to it at all. ${ }^{13}$

On the use of 'fante' dialect in teaching reading, Cramer asserts that failure to read to some extent exists among non-standard speakers and may be partially attributed to a mismatch between the dialects of the learners and the dialects of instruction. The more divergence there is between the dialect of the learners, the more difficult will be the task of learning. It is well established that reading to children supports learning to read. ${ }^{14}$ It is also recognized that reading aloud also supports writing since it supplies models for writing and enriches the stores of language available for writing. ${ }^{15}$

Cramer conducted a study on fourth-grade children's spelling as part of a large study comparing the language experience approach (LEA) to basal approach. He found out that the fourth-grade children who used invented spelling quickly became superior spellers than their basal counterparts and they maintained their superior achievement across six.

Even though this study is not a comparative one, it has been used to portray the different approaches teachers could use in preparing children to learn to read. It is quite unfortunate to have such answers from the headteacher of the school. Her negligence for not properly supervising her teachers, her lack of reading skills, knowledge and appropriate reading strategies been a disadvantage to herself and the teachers. The Ghana Education Service (G.E.S) must ensure adequate provision of human and material resources needed for effective reading supervision.

\section{SUMMARY OF FINDINGS}

The findings indicated that the studied population suffered from reading cognitive difficulties. Again, the lack of confidence in the use of spoken English language also contributed to the poor reading habits. Furthermore, it was also realized that pupils had inadequate oral reading skills acquisition to inadequate reading strategies deployed by teachers. Finally, negligence by headteachers to play her mandatory supervisory role on teachers to ensure the best of reading skill acquisition among others.

8 C. Donani, \& M. Avoke. (1996). Children with Learning Disabilities in J.S.S. 1, Winneba Township; Ghanaian Journal of Special Education. 3(1), 64-73.

9 L. S. Vygotsky, (1962) Thought and Language. Cambridge, MA: MIT Press.

10 C. Barnitz, (1980). The Analysis of Word Sounds by young Children. British Journal of Psychology, 34,158-170.

11 R. G. Lomax, L.M McGee, Young Children's Concepts about Print and Reading (New York City,1987).

12 L. A. Bader, Bader Reading and Language Inventory (4th ed.) Columbus OH: Merrill Prentice Hall, 2002.

13 J. N. Briton, (2002). Language and the Nature of Learning: An Individual Perspective: In J. R. SQUIRE, J. R. (ed.). The Teaching of English (Chicago: University of Chicago Press.

14 R. L. Cramer, Creative Power: The Nature and Nurture of Children's Assessment in Reading and Writing. New York: Addison Wesley Longman, 2001

15 R. L. Cramer, The Language Arts: A balanced Approach to teaching Reading, Writing, Listening, Talking and thinking, New York: Pearson Education Inc. 


\section{RECOMMENDATION}

As a result of the findings of the study, the following recommendations were made to reduce the factors which militated against the pupils reading performance at UPPS:

1. Pupils with reading difficulties must be given more time to read in order to overcome their problems. The teachers should pay attention to those pupils to enable them to perform better in reading fluently. Teachers need to model reading for children to also learn.

2. The School Committee Head, in collaboration with the Parent Teachers Association (P.T.A), should set up community and classroom libraries to motivate pupils to patronize the place because library development is a critical element of a reading society.

3. The school library should be adequately equipped and staffed to render different forms of user services and it should be flexibly managed and organized well by the Parent Teacher Association (P.T. A) and the school administrative authorities to meet the special needs of the pupils.

4. The teachers should help promote reading by forming reading clubs in the school where interclass book schemes could be set for children to loan books; they have read to others to promote learning.

\section{CONCLUSION}

In conclusion, the paper identified the major inhibiting factors militating against effective reading skills acquisition at UPPS, basic four ' $b$ ' (South Campus) Winneba. It deployed tests, observation, and interviews as research tools to collect data. The findings revealed that $80 \%$ of the pupils had low reading skill attainments and that had affected them so much in all their academic endeavors. Based on the findings some recommendations were outlined for teachers and headteachers to promote the effective teaching and learning of reading.

\section{BIBLIOGRAPHY}

Bader, L. A., Bader Reading and Language Inventory $\left(4^{\text {th }}\right.$ ed.) Columbus OH: Merrill Prentice Hall, 2002.

Boison, N. C. Development and uses of a 100 High Frequency Sight Words Recognition List for Children with reading failure: in A. E Ama (ed.), Reading for all in Africans: Building Communities where Literacy Thieves. Newark, DE: International Reading Association. (2005), 76-79.

Boison, N. C. Identification and Remediation of Reading Difficulties (Dyslexia) of Primary School Children in Winneba, Ghana. International Journal of Multicultural Education. No. (1) (2007):113-126.

Briton, J. N. Language and the nature of learning: an individual perspective: In J. R. Squire, (ed.). The Teaching of English Chicago: University of Chicago Press, 2002.

Chief Examiners' Report. Basic Education Certificate Examination. Accra: The West African Examination Council, 2006.

Cramer, R. L. Creative Power: The Nature and Nurture of Children's Assessment in Reading and Writing. New York: Addison Wesley Longman, 2001.

Cramer, R. L. The Language Arts: A Balanced Approached to Teaching Reading, Writing, Listening, Talking and Thinking. New York: Pearson Education Inc., 2004.

Donani, C. \& Avoke, M. (1996). Children with Learning Disabilities in J.S.S. 1, Winneba Township; Ghanaian Journal of Special Education. 3(1), 64-73.

Etsey, K. "Causes of low academic performance of primary school pupils in the Shama Sub- Metro of Shama Ahanta

East Metropolitan Assembly (SAEMA) in Ghana", in proceedings of the Reginal Conference on Education in West Africa, 2005

Hook, S., Education for modern man: Wipf and Stock Publishers, 2020

Lomax, G. R. and McGee, L. M., Young Children's Concepts about Print and Reading (New York City,1987).

Oyetunde, J. U., (Ed)., Helping Children Become Good Readers: A Guide for Parents and Teachers. Jos: P.P Reading Association of Nigeria, 2000.

Vygotsky, S. L., Thought and Language. Cambridge, MA: MIT Press, 1962. 